\title{
Development of a flaming machine for the disinfection of poultry grow-out facilities
}

\author{
Michele Raffaelli, ${ }^{1}$ Marco Fontanelli, ${ }^{1}$ Christian Frasconi, ${ }^{1}$ Angelo Innocenti, ${ }^{2}$ \\ Lamberto Dal Re, ${ }^{2}$ Lia Bardasi, ${ }^{3}$ Giorgio Galletti, ${ }^{3}$ Andrea Peruzzi ${ }^{1}$ \\ ${ }^{1}$ Dipartimento di Scienze Agrarie, Alimentari e Agro-ambientali, Università di Pisa; \\ ${ }^{2}$ Azienda Sperimentale Mario Marani, Ravenna; ${ }^{3}$ Istituto Zooprofilattico Sperimentale \\ della Lombardia e dell'Emilia Romagna, Sezione Provinciale di Bologna, Italy
}

\begin{abstract}
Chemical treatments are commonly adopted for poultry house sanitation. In fact, ordinary floor disinfection is needed to deplete the pathogenic population (i.e. various species of bacteria and fungi) and reduce the risk of meat contamination. The increasing focus on the health of consumers and operators, as well as on food quality, has led farmers to consider alternative environmentally friendly methods. Research was carried out to set up a new machine for floor disinfection of poultry houses by open flame. The trials were run in controlled conditions in the laboratory of the University of Pisa, Italy, and on a private farm. The first experiment consisted of a series of test bench trials carried out to evaluate the efficacy and the adjustment of liquefied petroleum gas (LPG)-fed open flame burners on pre-inoculated steel plates. In the second experiment, the operative parameters of a
\end{abstract}

Correspondence: Michele Raffaelli, Dipartimento di Scienze Agrarie, Alimentari e Agro-ambientali, Università di Pisa, via del Borghetto 80, 56124 Pisa, Italy.

Tel. +39.050 .2218947 - Fax: +39.050 .2218966 .

E-mail: mraffaelli@agr.unipi.it

Key words: poultry house sanitation, flame disinfection, flaming machine.

Funding: this research was co-founded by the Emilia Romagna Region (L.R. 28/98), sub-plan 2005/2006.

Conference presentation: CIGR Conference, Quebec City, Canada, 2010. Paper 101077.

Acknowledgements: the authors are very grateful to Officine Mingozzi (http:/www.pirodiserbo.it) for building the machine for thermal disinfection, and in particular to Marco Mingozzi for all his help and support. The authors would also like to thank Roberta del Sarto, Calogero Plaia and all the staff of the University of Pisa and Azienda Sperimentale "Marani" who were involved in the project.

Received for publication: 31 January 2013.

Accepted for publication: 30 April 2013.

CCopyright M. Raffaelli et al., 2013

Licensee PAGEPress, Italy

Journal of Agricultural Engineering 2013; XLIV:e4

doi:10.4081/jae.2013.e4

This article is distributed under the terms of the Creative Commons Attribution Noncommercial License (by-nc 3.0) which permits any noncommercial use, distribution, and reproduction in any medium, provided the original author(s) and source are credited. custom-built $1.5 \mathrm{~m}$ wide mounted flaming machine were determined and the biological effects of the treatment were compared to ordinary chemical treatments. The results obtained were very promising. Test bench trials showed a 4 -log reduction in $E$. coli, and microbial determinations carried out on-farm did not show any difference between thermal and chemical treatment. In addition, the cost estimation showed that thermal disinfection is approximately 4-fold cheaper than chemical sanitation methods. The effective working capacity of the machine was approximately $1700 \mathrm{~m}^{2} \mathrm{~h}^{-1}$, and the LPG consumption was approximately $16 \mathrm{~kg}$ per $1000 \mathrm{~m}^{2}$. Flame disinfection of poultry grow-out facilities could represent a valid alternative to chemical disinfection.

\section{Introduction}

Reducing bacterial and fungal populations is a major issue in poultry and turkey houses (Payne et al., 2002, 2005; Mueller-Doblies et al., 2010). The presence of a high population of pathogenic bacteria in broiler grow-out houses can affect the health of the flock and lead to a loss in production (Reiber et al., 1990; Payne et al., 2002, 2005).

Moreover, contaminated meat represents a serious health risk for consumers, as some microorganisms such as Salmonella and Campylobacter can be very dangerous for humans (Mead and Scott, 1994; Payne et al., 2002, 2005). Contamination can occur both during the industrial processing of meats and during the growing phase of the broilers (Mead and Scott, 1994; Payne et al., 2002, 2005; Usha, 2012). Salmonella is contained in many foods, but raw meats, poultry, eggs, milk and dairy products are usually considered the main sources of infection for humans (Jones, 2011).

Chicken is believed to be one of the most common vehicles for transmission of Campylobacter (Ingmer, 2011). Cross-contamination in food processes occurs when pathogens are transferred from a contaminated product to a non-contaminated product (Carrasco et al., 2012). Campylobacter cross-contamination during industrial processing occurs because it sticks to cutting boards, knife blades, and hands, after cutting chilled, raw broiler parts (Usha, 2012). Campylobacter can also contaminate the crates that transport live poultry (Hastings $e t$ al., 2010), the slaughterhouses (Ellerbroek et al., 2010; Rejab et al., 2012), and the scalding water (Osiriphum et al., 2012). Colles and colleagues (2010) also found that the source of the majority of Campylobacter genotypes contaminating the flock through the slaughter process was the live flock.

A major issue for the poultry industry is thus to prevent meat contamination through bacterial population reduction programmes during the growing phase of animals and on-farm (Payne et al., 2002, 2005; Doyle and Erickson, 2012). Research has been carried out in Europe and the USA aimed at finding effective solutions to decrease dangerous microorganisms or significantly reduce their growth rate (Davies 
and Wray, 1995; Payne et al., 2002; Gradel et al., 2004, 2005; Payne et al., 2005). A study conducted in Germany shows that the entrance of a Campylobacter positive flock in the abattoir resulted in contamination of the abattoir environment at almost all stages of the slaughter line (Ellerbroek et al., 2010).

Broilers can be contaminated from several sources, such as animal feed (Jones, 2011) and the environment where the flock is reared (Payne et al., 2002). Large amounts of faeces contained in the litter can contribute to the increase in pathogens (Payne et al., 2002). Rodents inhabiting poultry farms can also contribute to spreading pathogens (Mehmood et al., 2012).

Recent studies have shown that a considerable reduction in bacterial population can be achieved by removing the old litter followed by cleaning and disinfecting the facilities. This sanitation process usually takes place between the end of a growing cycle and the beginning of the following one, as broiler houses are not generally cleaned during the growing cycle. Disinfection is usually carried out with specific chemical sanitisers together with a great quantity of water to rinse the floor (Fate et al., 1985; Eckman, 1994; Marin et al., 2009). A common concern regarding food health and the application of potentially dangerous chemical products, as well as the problems related to the disposal of treatment water, have led to the search for new solutions.

The use of thermal radiations represents a possible environmentally friendly disinfection/sanitation method within poultry rearing/poultry meat chain sectors. For example, Stringfellow and colleagues studied litter pasteurisation (2010). Steam plus exothermic compounds were tested in order to achieve a significant reduction in Salmonella spp. Further important scientific input has been provided by Kim et al. (2012) who tested the effects of the thermal inactivation of Salmonella in poultry litters. Ultraviolet (UV) light and dielectric barriers can also be adopted to effectively decontaminate chicken carcasses (Keklik et al., 2011; Chun et al., 2010; Haughton et al., 2011; Dirks et al., 2012).

A completely novel approach was adopted in this study: a flame weeding machine was developed and modified for an open flame thermal disinfection of broiler houses, in particular, the concrete floor and the base of the walls. Specific tests were carried out in order to evaluate this environmentally friendly technique which could provide a possible alternative to chemical disinfection in the between-flocks gap.

\section{Materials and methods}

\section{Controlled conditions experiment}

The experiment was carried out in the laboratory of Agricultural Machinery and Farm Mechanization of the Department of Agriculture, Food and Enviroment of the University of Pisa, Italy.

A specific test bench (Figure 1) was used to evaluate the effectiveness of a purpose-built open flame burner for poultry house floor thermal disinfection and to choose the best adjustment for subsequent trials carried out on-farm in the poultry houses. This bench had been used previously to evaluate the effects of different adjustments of specific burners for flame weeding. Artificially pre-inoculated steel plates were treated with an open flame cylinder-shaped burner (Figure 2).

The test bench compares several liquefied petroleum gas (LPG) pressures, driving speeds, burner settings (inclination and height) and burner typologies (Figure 1).

The burners are fixed into the frame of the test bench, while the targets of flaming are conducted to the flame through a specific chain belt. A burner was arranged frontally with respect to the advancement direction of the containers on the belt conveyor, simulating the operating conditions. The LPG supply was provided by a tank equipped with a

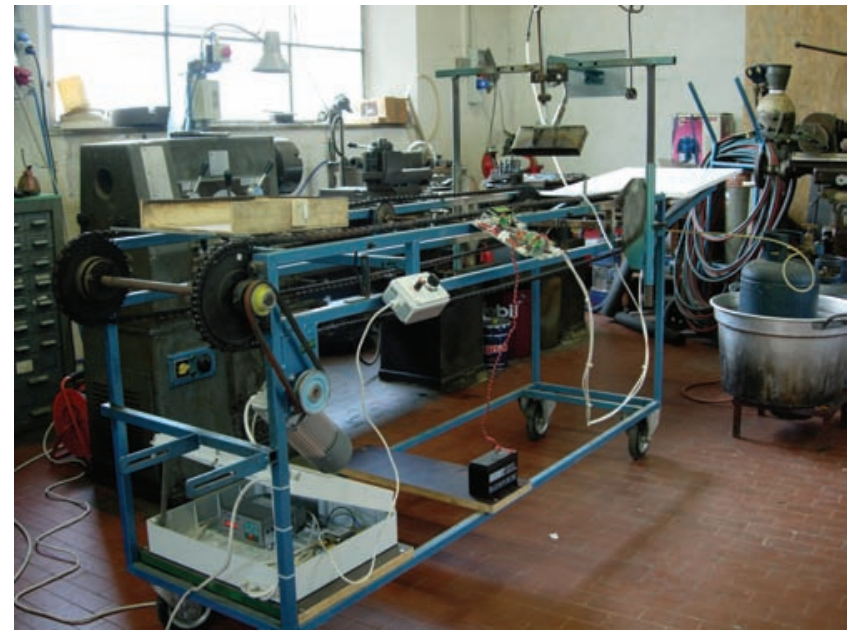

Figure 1. Test bench for flaming treatment in controlled conditions.

pressure regulator and a manometer, placed inside a heat exchanger and connected to the burners by pipes on which security switches and valves were placed. The test bench was equipped with an electronically-controlled electric motor (asynchronous three-phase, $180 \mathrm{~W}$, gear ratio 7.5) which kept the torque and the angular velocity constant. The chain was connected to the motor by two pulleys and a belt. The speed of the chain, which is constant thanks to the constant angular velocity of the motor, was controlled with a purpose-built digital tachometer.

The test bench was equipped with a slightly inclined smooth table to stop the containers containing the plates coming out from the chain.

Three thermal treatments were compared, as generated by different combinations of LPG pressure and working speed: $0.12 \mathrm{MPa}$ and $1 \mathrm{~km}$ $\mathrm{h}^{-1} ; 0.12 \mathrm{MPa}$ and $3 \mathrm{~km} \mathrm{~h}^{-1} ; 0.16 \mathrm{MPa}$ and $3 \mathrm{~km} \mathrm{~h}^{-1}$. LPG consumption (in $\mathrm{kg}$ per hour) and flame temperature were assessed.

Flame temperature was registered by a specific $R$ type bifilar thermocouple (platinum-rhodium, range $600-1700^{\circ} \mathrm{C}$ ). LPG tanks were weighed before and after 15 min of continuous working in order to evaluate LPG consumption (replicated 6 times). In addition, the temperature of the plates was registered 5 seconds (s) after the flaming treatment with a $K$ sensor.

Each plate, containing an inoculated marked surface of $1212 \mathrm{~cm}$, was identified, sterilised and packed with a paper sheet. Escherichia coli ATCC 25922 and Lactobacillus plantarum ATCC 8014 were used as contaminating bacteria. A bacterial suspension was prepared with horse serum at a concentration of $109 \mathrm{cfu} / \mathrm{mL}$.

Bacterial suspensions were subsequently titrated through decimal progressive dilution, by means of a micro method ( $20 \mathrm{~mL}$ per dilution) on blood agar for $E$. coli numeration ( $24 \mathrm{~h}$ of growth at $\left.37^{\circ} \mathrm{C}\right)$ and on de Man-Rogosa-Sharpe agar for L. plantarum numeration (48 $\mathrm{h}$ of growth at $37^{\circ} \mathrm{C}$ - microaerophilic, $10 \% \mathrm{CO}_{2}$ ). After removing the package, each plate was inoculated with $100 \mathrm{~mL}$ of $E$. coli and $100 \mathrm{~mL}$ of $L$. plantarum suspension. Two drops were placed within the marked surface and uniformly distributed with an L-shaped sterile spatula (Figure 3). E. coli ATCC 25922 was chosen since it is not a pathogenic strain in terms of human health under ordinary conditions, therefore it can be used in a common workshop, and because it belongs to the same family (Enterobacteriaceae) and the same group (Gram-negative) as Salmonella, which was the main target and the potential key pathogen in the poultry house. L. plantarum was used solely to observe whether 

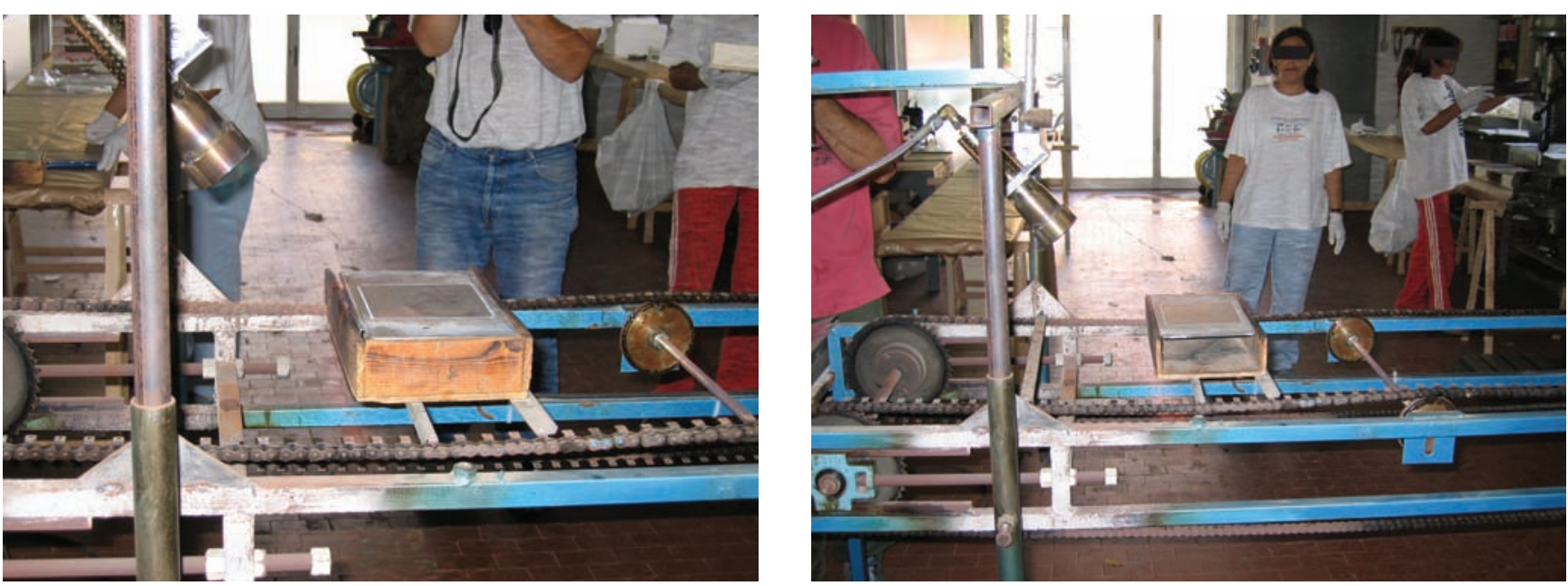

Figure 2. Flaming treatment of a pre-inoculated steel plate on the test bench.
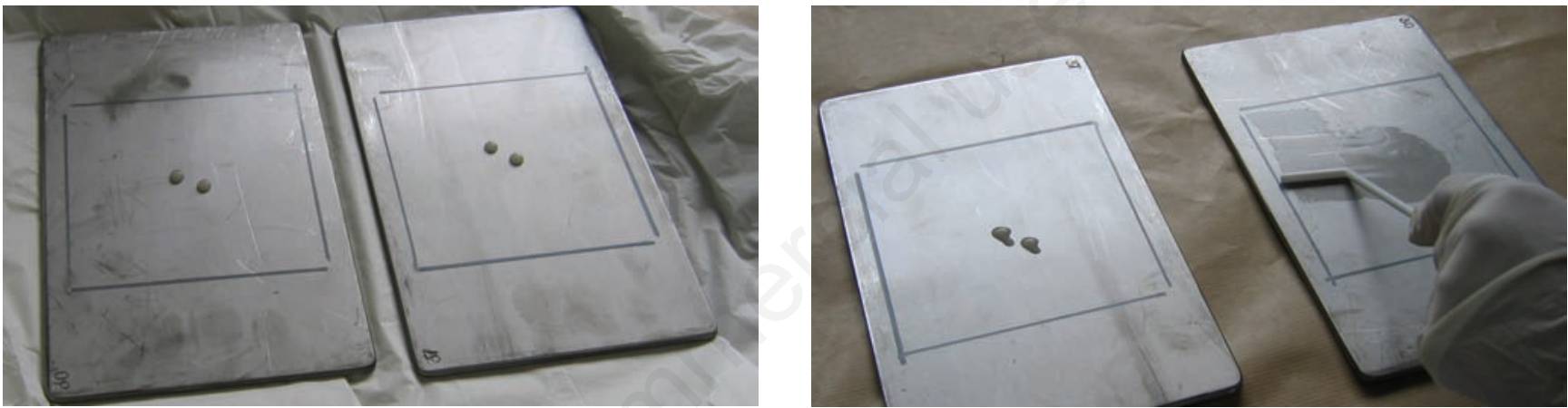

Figure 3. Inoculation of the steel plate.
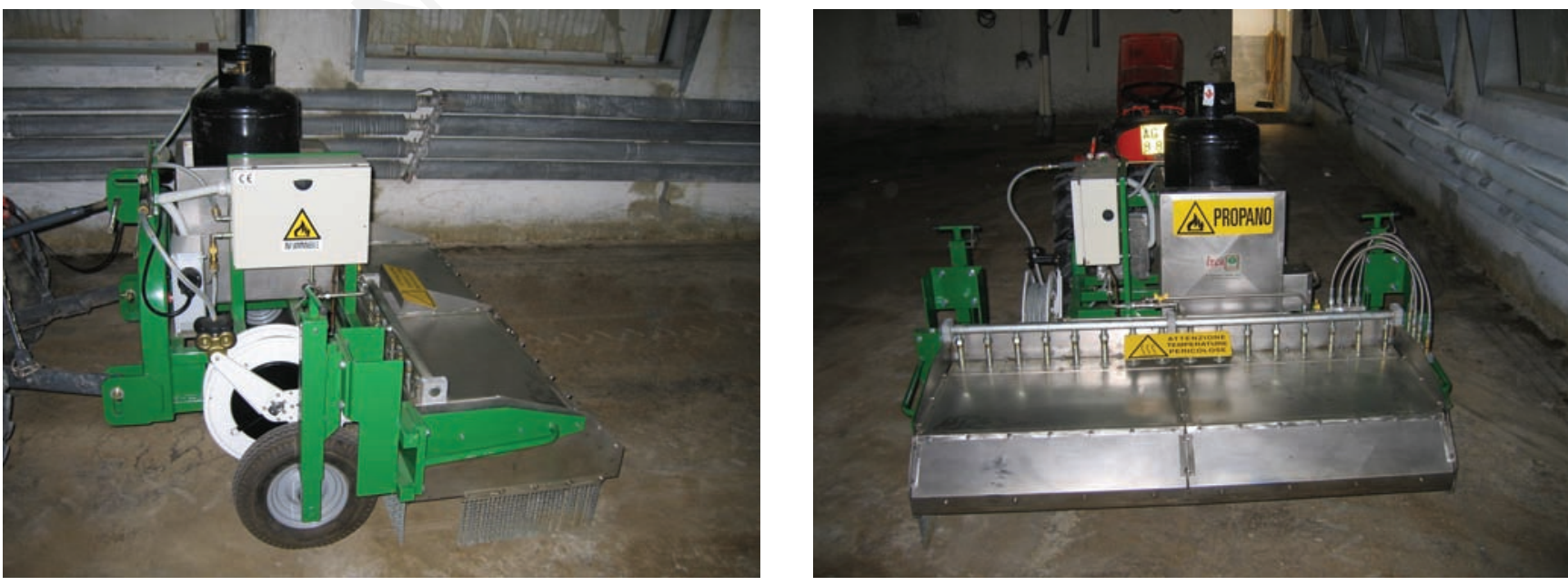

Figure 4. Lateral and rear views of the Officine Mingozzi flaming machine which can be coupled to a low power machine and used on the second floor of a poultry house. 
flaming could significantly reduce the Gram-positive population, as Gram-positive bacteria are generally characterised by higher thermoresistance than Gram-negative bacteria.

Treatments were performed after the plates had been left to dry out (replicated 6 times). Six plates were inoculated and used as untreated controls. Bacteria were recovered after treatment in order to evaluate its effectiveness. Only one operator carried out plate recovery in order to make this process as homogeneous as possible. Test tubes containing the bacterial suspension were maintained at refrigeration temperature before laboratory analysis. The surviving microorganisms were enumerated following the same procedures as described above. In addition, $E$. coli enumeration was carried out on both blood agar and violet red bile agar.

\section{Description of the innovative machine for flame disin- fection of poultry houses}

The semi-mounted machine was built and tested by officine Mingozzi in co-operation with the University of Pisa. Officine Mingozzi is based in Ferrara, Northern Italy, and specialises in farm machinery. It has many years of experience in flame weeding machines and flame sanitation in agriculture (Officine Mingozzi, 2013).

The prototype was purpose built for indoor treatments in broiler houses. This machine was then launched on the market as model PTE1600/1. The machine was small (1.60 m wide, $1.45 \mathrm{~m}$ long, weighing $280 \mathrm{~kg}$ ) and equipped with only one common commercial $25 \mathrm{~kg}$ LPG tank (total weight $50 \mathrm{~kg}$ ) (Figure 4).

These features enable this machine to be coupled with low-power tractors (10-12 kW) and used on the upper floor of broiler houses without any problems of excessive weight or manoeuvrability (Figure 5).

This machine was equipped with 20 cylinder-shaped open-flame burners (16 fixed under the hood, and 4 placed on the side of the machine in order to treat the base of walls) and a manual lance connected to a 10 m hose with an automatic purpose-built hose for LPG gas. The gas hose feeding the lance was steel reinforced in order to be heat resistant if accidentally flamed. With the manual lance it was possible to treat surfaces that would have been otherwise unreachable (Figure 5). The machine was equipped with a stainless steel cover in order to improve the efficiency of the thermal treatment. The machine was also equipped with a heat exchange system which uses part of the LPG contained in the tank, and an electronic panel placed on the hood of the tractor which reports any anomalies in functioning, such as burners turning off or a decrease in pressure. The heat exchange system prevents the tank from cooling, due to the change in LPG from liquid to gas. If the tanks cool down, the treatment would be compromised due to the consequent drop in gas pressure.

\section{On-farm trials}

The machine was tested in September 2006 at the Pratomagno farm in Central Italy, on two different upper floors of broiler houses of approximately $1000 \mathrm{~m}^{2}$ each (Figure 5). In the experimental trials, the machine was coupled with a Kubota B7100 tractor with $11.9 \mathrm{~kW}$ engine power weighing $489 \mathrm{~kg}$.

Ordinary chemical disinfection was compared to our flaming disinfection technique. The ordinary technique consisted in litter removal, equipment removal, equipment and ceiling washing, floor washing using a water jet and/or submersion plus detergents based on sodium and potassium, draining of washing water and dry chemical disinfection, and, finally, litter re-establishment. Our low environmental impact method was characterised by a prototype equipped with an LPG-fed open flame burners with a rear hood. Thermal treatments were carried out as an alternative to floor washing and dry disinfection.

Operative parameters (working width, working speed, theoretical and total working time, working efficiency and fuel and LPG consumption) and economic parameters were assessed and estimated with reference to an area of $1000 \mathrm{~m}^{2}$. The health of the flock was evaluated using steel plates placed on the floor after the two different treatments. Plates were the same as those described above. After flock removal, plates were recovered and analysed. Plate recovery was carried out by only one operator in order to make the process as homogeneous as possible. On each plate, the following microbial determinations were carried out: aerobic mesophilic bacteria (plate count agar, $48 \mathrm{~h}$ at $37^{\circ} \mathrm{C}$ ), Enterobacteriaceae (violet red bile glucose agar, $24 \mathrm{~h}$ at $37^{\circ} \mathrm{C}$ ), sulphitereducing clostridia (tryptose sulfite cycloserine agar, $48 \mathrm{~h}$ at $37^{\circ} \mathrm{C}$ ), Salmonella spp.
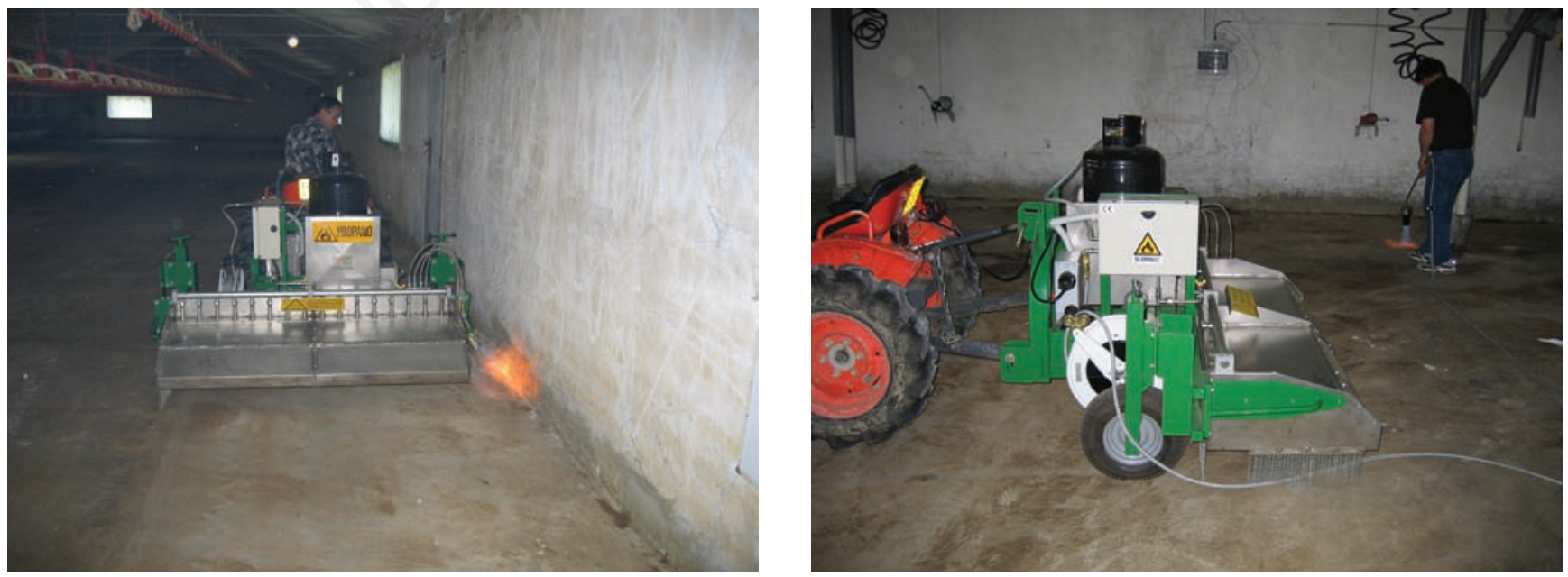

Figure 5. Flaming treatment in the broiler house: use of the lateral burners and the manual lance of the Officine Mingozzi flaming machine. This equipment was built in order to treat the base of the walls and the areas that the tractor was unable to access. 


\section{Statistical analysis and cost estimation}

For bacterial data, Kruskall-Wallis and multiple rank comparison tests were used for experiments under controlled conditions. On-farm data were processed with a median test. Analyses were performed with R software (version 2.5.1) (R Development Core Team, 2007).

Total machine cost per use was calculated by taking into account the standard methodology suggested on agricultural machinery and farm mechanisation texts (Biondi, 1999; Hunt, 2001; Lazzari and Mazzetto, 2005). Machinery system costs were calculated by summing fixed and variable costs. The depreciation rates of the flaming machine were calculated considering the purchase price of a new machine (9000€) and an economic life of ten years. The same procedure was adopted for tractor costs, considering a purchase price of $14,000 €$. An hourly rate of 15 $€ \mathrm{~h}^{-1}$ was considered for the tractor driver. The estimated cost for LPG was $2.1 €$ per kg. Labour costs for chemical disinfection were estimated on the basis of an hourly rate of $12.5 € \mathrm{~h}^{-1}$.

\section{Results}

\section{Controlled conditions experiment}

The temperature of the flame measured at the working level was the same for the two pressures tested. However, LPG consumption was 20\% higher for the highest pressure (Table 1). The temperature of the steel plates registered $5 \mathrm{~s}$ after the treatment was on average $28^{\circ} \mathrm{C}$, and ranged, depending on the treatment adjustment, from 27 to $29^{\circ} \mathrm{C}$. The temperature of the control plates was on average $25^{\circ} \mathrm{C}$, thus the temperature increase was very limited and varied from 2 to $4^{\circ} \mathrm{C}$. This does not justify a biological effect, probably due to the sudden temperature increase and to the direct contact between flame and the microorganisms (Table 2). The microbiological results are shown in Figure 6. Recovery of $E$. coli was considerably lower for treated plates as flaming achieved significant reductions in bacterial population. This difference was significant with the Kruskall-Wallis test $(\mathrm{P}<0.01)$ and also for the multiple comparison test. A maximum 4-log reduction was achieved when the combination $0.12 \mathrm{MPa}$ pressure-1.0 $\mathrm{km} \mathrm{h}^{-1}$ speed was applied. Therefore, this adjustment, which was the best of those tested, was adopted on farm. Lactobacilli, as expected, showed a higher recovery, as their superior tolerance to heat is well known. However, statistical tests again showed a significant decrease in bacterial population (which is very promising considering the target), and the best adjustment was again the same combination between working pressure and speed.

Table 1. Flame temperature and liquefied petroleum gas consumption per hour of burner.

\begin{tabular}{lcc} 
Pressure (MPa) & Temperature $\left({ }^{\circ} \mathrm{C}\right)$ & Consumption $\left(\mathrm{kg} \mathrm{h}^{-1}\right)$ \\
0.12 & 1220 & 2.5 \\
0.16 & 1220 & 3.0 \\
\hline
\end{tabular}

Table 2. Temperature of steel plates recorded 5 seconds after the flaming treatment.

\begin{tabular}{lcc} 
Pressure $(\mathrm{MPa})$ & Speed $\left(\mathrm{km} \mathrm{h}^{-1}\right)$ & Temperature $\left({ }^{\circ} \mathrm{C}\right)$ \\
0.16 & 1 & 29 \\
0.12 & 1 & 28 \\
\hline 0.16 & 3 & 27 \\
Untreated control & & 25 \\
\hline
\end{tabular}

\section{On-farm trials}

Machine performance in the two broiler houses is shown in Table 3.

Working speed ranged from 1.2 to $1.5 \mathrm{~km} \mathrm{~h}^{-1}$, and LPG pressure was $0.12 \mathrm{MPa}$ as this had been found to be the optimal adjustment during the previous series of trials. This technique required approximately 30 min and $15 \mathrm{~kg}$ of LPG to treat $1000 \mathrm{~m}^{2}$ (on average approx. $27 \mathrm{~kg} \mathrm{~h}^{-1}$ of LPG). Working efficiency (the ratio of the theoretical working time to the total time taken for a certain operation) was $85 \%$ and tractor fuel consumption was very low (approx. $0.3 \mathrm{~kg} / 1000 \mathrm{~m}^{2}$ ).

As far as treatment costs are concerned, the LPG $\left(56 € \mathrm{~h}^{-1}\right)$ was significantly higher than the other estimated expenses (costs of the machine, tractor, and driver) (Table 4). However, the total estimated costs per $1000 \mathrm{~m}^{2}$ were lower than $50 €$, a sustainable sum given that chemical disinfection requires $200 €$ only for labour ( 2 people for one whole working day) (Table 4).

Concerning the microbial analysis carried out after the flock growing cycle, the median test did not shown any significant difference between the two techniques (thermal and chemical). Some parameters are not reported because they were below the level of detection. For example, Salmonella spp. was not detected with either method (Table 5).

\section{Discussion}

The disinfection of surfaces with adherent organic matter in broiler houses is crucial in order to reduce meat contamination from Salmonella or Campylobacter and typically entails chemical disinfectants, whose efficacy in dry conditions varies considerably depending on the active ingredient (Gutierrez-Martin et al., 2011; McLaren et al., 2011). In this context, the use of the open flame, in the light of the positive results obtained,

Table 3. Performance of the flaming machine during on-farm trials in broiler houses.

\begin{tabular}{lcc} 
Operative performances & & Results \\
Engine power & $\mathrm{kW}$ & 12 \\
Working width & $\mathrm{m}$ & 1.5 \\
\hline Working speed & $\mathrm{km} / \mathrm{h}$ & $1.2-1.5$ \\
Theoretical working time & $\mathrm{h} / 1000 \mathrm{~m}^{2}$ & $0.45-0.54$ \\
\hline Total working time & $\mathrm{h} / 1000 \mathrm{~m}^{2}$ & $0.54-0.63$ \\
Working efficiency & $\%$ & $83-86$ \\
\hline Effective working capacity & $\mathrm{m}^{2} / \mathrm{h}$ & $1590-1850$ \\
Fuel consumption & $\mathrm{kg} / 1000 \mathrm{~m}^{2}$ & $0.27-0.31$ \\
\hline LPG pressure & $\mathrm{MPa}$ & 0.12 \\
LPG consumption & $\mathrm{kg} / 1000 \mathrm{~m}^{2}$ & $14.5-16.9$ \\
\hline LPG, liquefied petroleum gas. & &
\end{tabular}

Table 4. Estimated costs for thermal and chemical disinfection.

\begin{tabular}{lcc} 
Cost items & & Costs \\
Flaming machine & $€ / \mathrm{h}$ & 2 \\
LPG feeding & $€ / \mathrm{h}$ & 56 \\
\hline Tractor (including driver) & $€ / \mathrm{h}$ & 22 \\
Total hourly costs of flaming & $€ / \mathrm{h}$ & 80 \\
\hline Total costs of flaming & $€ / 1000 \mathrm{~m}^{2}$ & 47 \\
Total labour costs of chemical disinfection* & $€ / 1000 \mathrm{~m}^{2}$ & 200
\end{tabular}

LPG, liquefied petroleum gas. *Not including costs of disinfectant or water. 
Table 5. Biological results of on-farm trials.

\begin{tabular}{|c|c|c|c|c|c|c|c|}
\hline \multirow[t]{2}{*}{ Farm } & \multirow[t]{2}{*}{ Assessment } & \multicolumn{3}{|c|}{ Flaming $\left(\mathrm{cfu} / \mathrm{cm}^{2}\right)$} & \multicolumn{3}{|c|}{ Ordinary (cfu/cm²) } \\
\hline & & Min & Median & Max & Min & Median & Max \\
\hline Broiler (1) & $\begin{array}{l}\text { Aerobic mesophilic bacteria } \\
\text { Enterobacteriaceae }\end{array}$ & $\begin{array}{l}1,050,000 \\
<150\end{array}$ & $\begin{array}{c}1,912,500 \\
125\end{array}$ & $\begin{array}{l}33,000,000 \\
375\end{array}$ & $\begin{array}{c}23,250 \\
<150\end{array}$ & $\begin{array}{c}1,672,500 \\
<150\end{array}$ & $\begin{array}{l}20,250,000 \\
225\end{array}$ \\
\hline Broiler (2) & $\begin{array}{l}\text { Aerobic mesophilic bacteria } \\
\text { Enterobacteriaceae }\end{array}$ & $\begin{array}{c}65,000 \\
20\end{array}$ & $\begin{array}{c}450,000 \\
166 \\
\end{array}$ & $\begin{array}{c}22,000,000 \\
775\end{array}$ & $\begin{array}{c}975 \\
98 \\
\end{array}$ & $\begin{array}{c}61,250 \\
500 \\
\end{array}$ & $\begin{array}{c}12,500,000 \\
950\end{array}$ \\
\hline
\end{tabular}

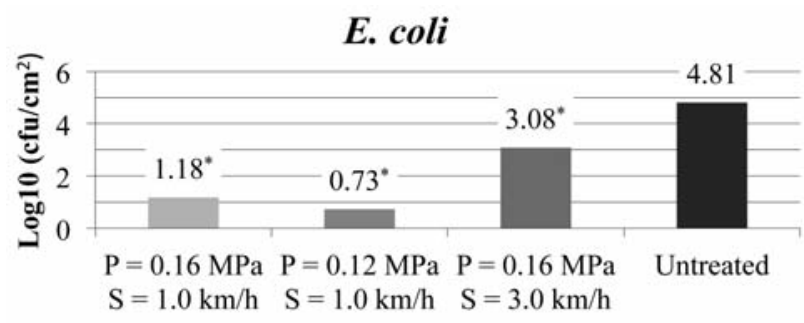

\section{L. plantarum}

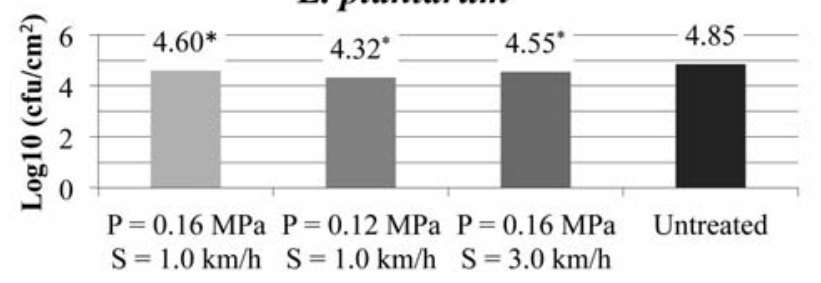

Figure 6. Microbial response to flaming treatments (mean values). *Significant differences $v s$ untreated controls.

could be taken into account as a promising low-environmental impact, residue-free and effective technique for the disinfection of poultry premises, in order to improve the safety of operators and consumers. However, other studies claim that the rearing period is not significant for meat contamination from Campylobacter (Kudirkiene et al., 2011), though tackling the problem on the individual farm is a good way to significantly reduce human infection from Salmonella (Gast, 2007; Namata et al., 2009; Vandeplas et al., 2010). In addition research has shown that Salmonella and Campylobacter should be controlled throughout the entire production chain (Cox and Pavic, 2010), and that the frequencies of Salmonella in the litter on the day of harvest and prior to placement are the best predictors of post-chill broiler carcass (Volkova et al., 2008). Litter pasteurisation may thus play a key role in poultry rearing, as disposing of it and replacing it can be very costly. Stringfellow and colleagues, 2010, tested a thermal treatment to reduce Salmonella Typhimurium in used poultry litters by steam, or exothermic compounds ( $\mathrm{CaO})$, or a combination of both. The results show that steam alone, $\mathrm{CaO}$ alone and steam plus $\mathrm{CaO}$ could significantly reduce Salmonella to undetectable levels. Steam alone was enough to cause a significant reduction in Salmonella of at least three orders of magnitude. The exposure time varied from 5 to $120 \mathrm{~min}$. However, the authors say that further research is needed to determine whether this technique is applicable from a practical point of view.

Stringfellow's approach is substantially different from ours, in which thermal radiation (open flame) is used to very quickly disinfect the bare floor of a broiler house between two growing cycles. Thermal inactivation of Salmonella in poultry litters was also tested by Kim et al., (2012) and a 7-log reduction was achieved by exposing litters to temperatures of 70 $80^{\circ} \mathrm{C}$ for $44-100 \mathrm{~min}$. Litter disinfection is necessary not only for its re-use in poultry rearing but also for agricultural land applications and disposal, as the presence of pathogenic microorganisms can be harmful to the envi- ronment (Kim et al., 2012; Stringfellow et al., 2010). Using flaming and other disinfection technologies in the poultry meat chain is a novel approach that could also be interesting for the meat processing stage. In fact, significant results have been achieved by using UV light for decontaminating chicken carcasses. A specific machine based on a pulsed UV light system was developed by Keklik et al. (2011). This machine was tested on chickens which were sprayed with an $E$. coli K12 inoculum. A $45 \mathrm{~s}$ long treatment achieved the best results ( $90 \%$ reduction). Similar results were achieved by Chun et al. (2010) and Haughton et al. (2011). Dirks et al. (2012) treated raw poultry with a non-thermal dielectric barrier discharge plasma which reduced Campylobacter jejuni and Salmonella enterica.

Morey and colleagues (2010) used physical methods to decontaminate processing facilities. UV light proved effective in decontaminating different kinds of conveyor belts from Listeria monocytogenes. The duration of the treatment varied from 1 to $3 \mathrm{~s}$.

\section{Conclusions}

We believe that flame disinfection of poultry grow-out facilities could represent a valid alternative to chemical disinfection: it is environmentally friendly, does not require floor washing or water disposal, and the treatment is very fast, economically sustainable and cheaper than ordinary chemical sanitation methods. This technique is also gaining interest in the USA where flamers are used for poultry house sanitation (Watkins et al., 1999). Under controlled conditions, trials gave clear indications concerning burner adjustment and effectiveness to help set up effective new machines and on-farm treatments. Innovative machines meant treatments could be carried out with good operative performances in a problematic context. Similar results between thermal and chemical disinfection were observed on farms using different microbiological parameters (in particular, aerobic mesophilic bacteria and Enterobacteriaceae). In the future, it might be possible to improve the machine and treatment performances with specific experiments. In addition, further experiments are needed to test the effects of the different techniques after repeated broiler growing cycles. In particular, specific analysis of the meat before slaughter could provide important information. Our machine is, in fact, being successfully used by farmers and is now being marketed by Officine Mingozzi (model PTE1600/1), thus further longer-term microbial on-farm tests may be possible.

\section{References}

Biondi P., (ed). 1999. Meccanica agraria, le macchine agricole. UTET, Torino, Italy, pp 547-71. [In Italian]

Carrasco E., Morales-Rueda A., Garcia-Gimeno R.M. 2012. Cross-contamination and recontamination by Salmonella in foods: a review. Food Res. Int. 45:545-56.

Chun H.H., Kim J.Y., Lee B.D., Yu D.J., Song K.B. 2010. Effect of UV-C irradi- 
ation on the inactivation of inoculated pathogens and quality of chicken breasts during storage. Food Control. 21:276-80.

Colles F.M., McCarthy N.D., Sheppard S.K., Layton R., Maiden M.C.J. 2010. Comparison of Campylobacter populations isolated from a free-range broiler flock before and after slaughter. Int J Food Microbiol. 137:259-64.

Cox J.M., Pavic A. 2010. Advances in enteropathogen control in poultry production. J. Appl. Microbiol. 108:745-55.

Davies R.H., Wray C. 1995. Observations on disinfection regimens used on Salmonella Enteritidis infected poultry units. Poult. Sci. 74:638-47.

Dirks B.P., Dobrynin D., Fridman, G., Mukhin, Y., Fridman, A., Quinlan J.J. 2012. Treatment of raw poultry with nonthermal dielectric barrier discharge plasma to reduce campylobacter jejuni and salmonella enterica. J. Food Prot. 75:22-8.

Doyle M.P., Erickson M.C. 2012. Opportunities for mitigating pathogen contamination during on-farm food production. Int. J. Food Microbiol. 152:54-74.

Eckman M.K. 1994. Chemicals used by the poultry industry. Poult. Sci. 73:1429-32.

Ellerbroek L.I., Lienau1 J.A., Klein G. 2010. Campylobacter spp. in broiler flocks at farm level and the potential for cross-contamination during slaughter. Zoonoses Public Health. 57:e81-8.

Fate M.A., Skeeles J.K., Whitfill C.E., Russell I.D. 1985. Evaluation of four disinfectants under poultry grow-out conditions using contact agar sampling technique. Poult. Sci. 64:629-33.

Gast R.K. 2007. Serotype-specific and serotype-independent strategies for preharvest control of food-borne Salmonella in poultry. Avian. Dis. 51:817-28.

Gradel K.0., Randall L., Sayers A.R., Davies R.H. 2005. Possible associations between Salmonella persistence in poultry houses and resistance to commonly used disinfectants and a putative role of mar. Vet. Microbiol. 107:127-38.

Gradel K.O., Sayers A.R., Davies R.H. 2004. Surface disinfection tests with Salmonella and a putative indicator bacterium, mimicking worst-case scenarios in poultry houses. Poult. Sci. 83:1636-43.

Gutierrez-Martin C.B., Yubero S., Martinez S., Frandoloso R., RodriguezFerri E.F. 2011. Evaluation of efficacy of several disinfectants against Campylobacter jejuni strains by a suspension test. Res. Vet. Sci. 91:e447.

Hastings R., Colles F.M., McCarthy N.D., Maiden M.C.J., Sheppard S.K. 2010. Campylobacter genotypes from poultry transportation crates indicate a source of contamination and transmission. J. Appl. Microbiol. 110:26676.

Haughton P.N, Lyng J.G., Morgan D.J., Cronin D.A., Fanning S., Whyte P. 2011. Efficacy of high-intensity pulsed light for the microbiological decontamination of chicken, associated packaging, and contact surfaces. Foodborne Pathog. Dis. 8:109-17.

Hunt D. 2001. Farm power and machinery management. Waveland Press Inc., Long Grove, IL, USA.

Ingmer H. 2011. Challenges of Campylobacter jejuni in poultry production. Int. J. Food. Microbiol. 145:S110.

Jones FT. 2011. A review of practical Salmonella control measures in animal feed. J. Appl. Poult. Res. 20:102-13.

Kim J., Diao J., Shepherd Jr. M.W., Singh R., Heringa S.D., Gong C., Jiang X. 2012. Validating thermal inactivation of Salmonella spp. in fresh and aged chicken litter. Appl. Environ. Microbiol. 78:1302.

Keklik N.M., Demirci A., Bock R.G. 2011. Surface decontamination of whole chicken carcasses using a pilot-scale pulsed UV light system. Transact. ASABE. 54:993-1000.

Kudirkiene E., Buneviciene J., Brøndsted L., Ingmer H., Olsen J.E., Malakauskas M. 2011. Evidence of broiler meat contamination with post-disinfection strains of Campylobacter jejuni from slaughterhouse. Int. J. Food. Microbiol. 145:116-20.
Lazzari M., Mazzetto F., (eds). 2005. Prontuario di meccanica agraria e meccanizzazione. Reda Edizioni, Torino, Italy, pp 62-79. [In Italian]

Marin C., Hernandiz A., Lainez M. 2009. Biofilm development capacity of Salmonella strains isolated in poultry risk factors and their resistance against disinfectants. Poult. Sci. 88:424-31.

McLaren I., Wales A., Breslin M., Davies R. 2011. Evaluation of commonlyused farm disinfectants in wet and dry models of Salmonella farm contamination. Avian Patol. 40:33-42.

Mead G.C., Scott M.J. 1994. Coagulase-negative staphylococci and coliform bacteria associated with mechanical defeathering of poultry carcasses. Appl. Microbiol. 18:62-4.

Mehmood A., Ansari M.S., Akhter S., Khan A.A., Hussain I., Shams-UlHassan, Qureshi T.Z., Rakha, B.A. 2012. Occurrence of pathogenic bacteria in small mammals - Inhabiting poultry farms of Rawalpindi/ Islamabad, Pakistan. Pak. J. Zool. 44:1185-7.

Morey A., McKee S.R., Dickson J.S., Singh M. 2010. Efficacy of ultraviolet light exposure against survival of listeria monocytogenes on conveyor belts. Foodborne Pathog. Dis. 7:737-40.

Mueller-Doblies D., Carrique-Mas J.J., Sayers A.R., Davies R.H. 2010. A comparison of the efficacy of different disinfection methods in eliminating Salmonella contamination from turkey houses. J. Appl. Microbiol. 109:471-9.

Namata H., Welby S., Aerts M., Faes C., Abrahantes J.C., Imberechts H., Vermeersch K., Hooyberghs J, Meroc E., Mintiens K. 2009. Identification of risk factors for the prevalence and persistence of Salmonella in Belgian broiler chicken flocks. Prev. Vet. Med. 90:211-22.

Officine Mingozzi. 2013. Parliamo di...pirodiserbo. Available from: http//www.pirodiserbo.it [In Italian]

Osiriphun S., Tuitemwong P., Koetsinchai W., Tuitemwong K., Erickson L.E. 2012. Model of inactivation of Campylobacter jejuni in poultry scalding. J. Food. Eng. 110:38-43.

Payne J.B., Kroger E.C., Watkins S.E. 2002. Evaluation of litter treatments on Salmonella recovery from poultry litter. J. Appl. Poult. Res. 11:239-43.

Payne J.B., Kroger E.C., Watkins S.E. 2005. Evaluation of disinfectant efficacy when applied to the floor of poultry grow-out facilities. J. Appl. Poult. Res. 14:322-9.

R Development Core Team. 2007. R: A language and environment for statistical computing. R Foundation for Statistical Computing, Vienna, Austria. Available from: http//www.R-project.org

Reiber M.A., Hierholzer R.E., Adams M.H., Colberg M., Izat A.L. 1990. Effect of litter condition on microbiological quality of freshly killed and processed broilers. Poult. Sci. 69:2128-33.

Rejab S.B.M.A, Zessin K.-H.B, Fries R.C, Patchanee P.D. 2012. Campylobacter in chicken carcasses and slaughterhouses in Malaysia. Asian J. Trop. Med. 43:96-104.

Stringfellow K., Caldwell D., Lee J., Byrd A., Carey J., Kessler K., McReynolds J., Bell A., Stipanovic R., Farnell M. 2010. Pasteurization of chicken litter with steam and quicklime to reduce Salmonella Typhimurium. J. Appl. Poult. Res. 19:380-6.

Usha M.R.A, Tunung R.A, Chai L.C.A, Ghazali F.M.A, Cheah Y.K.B, Nishibuchi M.C, Son R.A. 2012. A study on Campylobacter jejuni cross-contamination during chilled broiler preparation. Int. Food Res. J. 17:107-15.

Vandeplas S., Dubois Dauphin R, Beckers Y., Thonart P., Théwis A. 2010. Salmonella in chicken: current and developing strategies to reduce contamination at farm level. J. Food Prot. 73:774-85.

Volkova V.V., Bailey R.H., Rybolt M.L, Dazo-Galarneau K., Hubbard S.A., Magee D., Byrd J.A., Wills R.W. 2009. Inter-relationships of Salmonella status of flock and grow-out environment at sequential segments in broiler production and processing. Zoonoses Public Health. 57:463-75.

Watkins S.E., Payne J.B., Waldroup A.L. 1999. The bio-burner: a new tool in poultry sanitation. Avian Advice. 1:2-4. Available from: http//www. avianadvice.uark.edu 